\title{
Performance of Lactating Dairy Cows Fed Corn as Whole Plant Silage and Grain Produced from a Glyphosate-Tolerant Hybrid (event NK603)
}

\author{
I. R. Ipharraguerre, ${ }^{*}$ R. S. Younker, ${ }^{*, 1}$ J. H. Clark, ${ }^{*}$ \\ E. P. Stanisiewski, $†$ and G. F. Hartnell† \\ *Department of Animal Sciences \\ University of Illinois, Urbana 61801 \\ †Monsanto Company \\ St. Louis, MO 63198
}

\begin{abstract}
Sixteen multiparous Holstein cows averaging $74 \mathrm{~d}$ in milk were used in a replicated $4 \times 4$ Latin square to compare the effects on animal performance of feeding whole plant silage and grain from a glyphosate-tolerant corn hybrid (event NK603), a nontransgenic control hybrid, and two commercial nontransgenic hybrids (DK647 and RX740). The grain and silage from the four corn hybrids were produced using the same procedures and under similar agronomic conditions at the University of Illinois. On a dry matter (DM) basis, diets contained $30 \%$ corn silage and $27.34 \%$ corn grain produced either from event NK603, a nontransgenic control, or commercial hybrids. Apart from the DM content of silages, the chemical composition of both grain and silage produced from the four corn hybrids were substantially equivalent. Feeding diets that contained event NK603 and DK647 hybrids tended to decrease DM intake (DMI) compared with the control nontransgenic and RX740. The intakes of crude protein (CP), acid and neutral detergent fiber, and nonfiber carbohydrates were not different for cows fed event NK603 and control diets. The RX740 diet resulted in the highest intakes of fiber and CP, whereas the DK647 diet resulted in the lowest intake of CP. These differences in nutrient intake arose from small variations in both the DMI and the chemical composition of feed ingredients and experimental diets. Production of milk and 3.5\% fatcorrected milk; milk fat, $\mathrm{CP}$, and true protein percentage and yield; milk urea $\mathrm{N}$; milk total solids percentage and yield; and somatic cell count were not affected by treatments. These data indicate that the stable insertion of the gene that confers tolerance to glyphosate (event NK603) in the corn line used in this experiment
\end{abstract}

Received June 17, 2002.

Accepted July 11, 2002.

Corresponding author: Jimmy H. Clark; e-mail: jhclark@uiuc.edu.

${ }^{1}$ Current address: Milk Specialties Company, P.O. Box 278, Dundee, IL 60118. does not affect its chemical composition and nutritional value for lactating dairy cows when compared with conventional corn.

(Key words: glyphosate-tolerant corn, production by dairy cattle, genetically enhanced crops)

Abbreviation key: CP4 EPSPS = modified enzyme 5- enolpyruvylshikimate-3-phosphate synthase, DON = deoxynivalenol, EPSPS = enzyme 5-enolpyruvylshikimate-3-phosphate synthase.

\section{INTRODUCTION}

At the present time, corn hybrids that were genetically enhanced to improve crop protection against specific insects (e.g., European Corn Borer) and (or) resistance to weed controlling herbicides are available in the marketplace. Just a few years after their introduction, these hybrids were extensively planted in the United States, reaching a maximum of about $37 \%$ of the total area planted to corn in 1999 (USDA, 2001). For 2001, the USDA (2001) projected that about $24 \%$ of the acreage cultivated with corn in the United States would be planted with hybrids developed using this technology.

In 1998, a variety of corn tolerant to glyphosate (Roundup Ready event GA21) was marketed for the first time in the United States (Sidhu et al., 2000). Glyphosate, the active ingredient of the herbicide Roundup, kills susceptible plants by restraining the biosynthesis of aromatic amino acids through the inhibition of the enzyme 5-enolpyruvylshikimate-3-phosphate synthase (EPSPS; Steinrüken and Amrhein, 1980). Tolerance to this herbicide was achieved by the stable insertion of a gene that codifies for a modified corn EPSPS (CP4 EPSPS; Sidhu et al., 2000). Because CP4 EPSPS is not inhibited by glyphosate, the receptor corn line can successfully synthesize and meet its needs for aromatic amino acids even in the presence of this herbicide (Sidhu et al., 2000). Provided that the genome of corn hybrids tolerant to glyphosate was only subjected to this modification (i.e., expression of CP4 EPSPS), it is expected that their chemical composition 
and nutritional value for livestock will remain similar to that of the nontransgenic lines with a similar genetic background. In fact, results from experiments in which corn hybrids tolerant to glyphosate that are currently available on the market and that were evaluated as feed for livestock confirm this hypothesis (Clark and Ipharraguerre, 2001). For instance, Sidhu et al. (2000) found similar contents of moisture, protein, fat, ash, carbohydrates, $\mathrm{ADF}, \mathrm{NDF}, \mathrm{Ca}$, and $\mathrm{P}$ in grain and whole plant green chop from a glyphosate-tolerant hybrid (GA21), its nontransgenic line (DK626), and five commercial corn hybrids. Moreover, the concentration of amino acids and fatty acids in grain from those seven hybrids were not significantly different. Additionally, Donkin (personal communication, 2000) observed that the DMI, milk yield, and milk composition of lactating dairy cows fed whole plant silage and grain produced from either a glyphosate-tolerant hybrid (GA21) or the parental corn line (DK626) were not different. More recently, data supporting these findings from experiments with chickens (Gaines et al., 2001a; Taylor et al., 2001a, 2001b) and pigs (Gaines et al., 2001b; Stainisiewski et al., 2001) have become available. Nevertheless, published data from experiments conducted to compare the performance of lactating dairy cows fed either glyphosate-tolerant or nontransgenic corn are not available. In addition, as glyphosate tolerance is conferred to novel corn lines with desirable agronomic characteristics, more experiments aiming to explore the nutritional value of these hybrids as feed for lactating dairy cows are needed. Therefore, the objectives of this study were to compare the effects on DMI, milk production, and milk composition of lactating dairy cows fed whole plant silage and grain produced from a glyphosate-tolerant corn hybrid (event NK603), its nontransgenic control of a similar genetic background, and two commercial nontransgenic hybrids.

\section{MATERIALS AND METHODS}

\section{Corn Grain and Corn Silage Production}

From May 5 to May 8, 2000, four corn hybrids were planted in nonadjacent plots at the Agricultural Research Farm of the University of Illinois at UrbanaChampaign to produce both grain and silage. The four hybrids were: 1) a glyphosate-tolerant (event NK603) hybrid, 2) a nontransgenic control hybrid of a similar genetic background, and 3) two commercial nontransgenic hybrids (DK647, DeKalb Seeds, DeKalb, IL; and RX740, Asgrow, Des Moines, IA). The size of the plots was 6.0 ha for event NK603, 6.0 ha for the nontransgenic control, 13.5 ha for DK647, and 14.0 ha for RX740. Days to relative maturity were 110 to 115 (2450 to 2550 heat units) for each of the corn hybrids studied.
Except for the application of Roundup to the plot containing glyphosate-tolerant plants, all hybrids were planted, grown, and harvested under similar agronomic conditions by personnel of the University of Illinois. Corn plots committed to produce grain were harvested at 85.4, 85.3, 85.4, and 86.5\% DM for NK603 (October 19, 2000), nontransgenic control (October 18, 2000), DK647 (October 12, 2000), and RX740 (October 11-12, 2000) hybrids, respectively. After harvest, the grain was stored separately at the Feed Mill of the University of Illinois until initiation of the experiment on November 22,2000 . The corn plots dedicated to produce silage were harvested on August 31, 2000, at about 1/2-milk line stage of maturity, chopped (New Holland model 1900 Forage Harvester without a kernel processor), and stored using a bagger (Ag-Bagger) in separate bags (TriDura Storage Bags, $2.73 \mathrm{~m}$ wide and made of \#4 plastic with a white exterior layer and black inner layer) at the Dairy Farm of the University of Illinois. At harvest, the DM percentage of whole-fresh-cut plants was 39.7, 40.6, 40.8, and 33.6 for NK603, nontransgenic control, DK647, and RX740 hybrids, respectively.

\section{Animals, Experimental Design, and Diets}

Sixteen multiparous Holstein cows, averaging 41.4 $\mathrm{kg}$ of milk/d, $623 \mathrm{~kg}$ of BW, and 74 DIM at the onset of the experiment, were used in four $4 \times 4$ Latin squares conducted concurrently according to procedures approved by the University of Illinois Laboratory Animal Care Advisory Committee. Initially, cows were assigned to squares according to DIM at the beginning of the experiment and milk production during the previous 2 wk. Thereafter, cows within each square were randomly assigned to one of the four dietary treatment sequences. Each experimental period consisted of $28 \mathrm{~d}$; the first $14 \mathrm{~d}$ were used to adapt cows to treatments and the remaining $14 \mathrm{~d}$ were used for data collection.

Four experimental diets containing the same forage to concentrate ratio (52 to $48 \%$ on DM basis) were prepared with different sources of corn supplied as silage and grain (Table 1). Specifically, diets contained 30\% corn silage and $27.34 \%$ corn grain (DM basis) produced either from NK603, nontransgenic control, DK647, or RX740 hybrids (Table 1). The remaining dietary ingredients were provided from the same source and in the amounts needed to meet the NRC (2001) nutrient requirements (Table 1). Throughout the entire experiment, NK603 diet was prepared and fed with different equipment in order to avoid contamination of the other diets with silage or grain of transgenic origin. Diets were fed as TMR twice daily at 1000 and $1700 \mathrm{~h}$ in amounts to ensure $10 \%$ orts. Additionally, TMR were adjusted weekly to reflect changes in DM content of 
Table 1. Ingredient composition of the experimental diets.

\begin{tabular}{|c|c|c|c|c|}
\hline \multirow[b]{2}{*}{ Ingredient } & \multicolumn{4}{|c|}{ Treatments } \\
\hline & Glyphosate-tolerant $^{1}$ & $\begin{array}{l}\text { Nontransgenic } \\
\text { control }\end{array}$ & DK647 & $\mathrm{RX} 740$ \\
\hline & 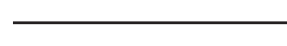 & - $(\%$ of $\mathrm{DM})$ & & \\
\hline Alfalfa silage & 22.00 & 22.00 & 22.00 & 22.00 \\
\hline \multicolumn{5}{|l|}{ Corn silage } \\
\hline Glyphosate-tolerant & 30.00 & & $\ldots$ & $\ldots$ \\
\hline Control & $\ldots$ & 30.00 & & $\ldots$ \\
\hline DK647 & $\ldots$ & $\ldots$ & 30.00 & $\ldots$ \\
\hline $\mathrm{RX740}$ & $\ldots$ & $\ldots$ & $\ldots$ & 30.00 \\
\hline \multicolumn{5}{|l|}{ Ground shelled corn } \\
\hline Glyphosate-tolerant & 27.34 & & $\ldots$ & $\ldots$ \\
\hline Control & $\ldots$ & 27.34 & $\ldots$ & $\ldots$ \\
\hline DK647 & $\ldots$ & $\ldots$ & 27.34 & \\
\hline $\mathrm{RX740}$ & $\ldots$ & $\ldots$ & $\ldots$ & 27.34 \\
\hline Soybean meal, $48 \%$ CP & 17.00 & 17.00 & 17.00 & 17.00 \\
\hline Sodium bicarbonate & 1.00 & 1.00 & 1.00 & 1.00 \\
\hline Sodium chloride & 0.25 & 0.25 & 0.25 & 0.25 \\
\hline Dicalcium phosphate & 0.66 & 0.66 & 0.66 & 0.66 \\
\hline Limestone & 0.90 & 0.90 & 0.90 & 0.90 \\
\hline Mineral and vitamin $\operatorname{mix}^{2}$ & 0.25 & 0.25 & 0.25 & 0.25 \\
\hline Magnesium oxide & 0.18 & 0.18 & 0.18 & 0.18 \\
\hline Sodium sulfate & 0.42 & 0.42 & 0.42 & 0.42 \\
\hline
\end{tabular}

forages and concentrate mixtures by drying the forages and concentrates overnight at $105^{\circ} \mathrm{C}$.

Cows were housed in individual tie stalls equipped with water bowls and bedded with sawdust. During the experiment, cows were milked twice daily at 0300 and $1500 \mathrm{~h}$ and were let outside in dry lot to exercise from 0700 to 0900 daily.

\section{Sampling, Measurements, and Analyses}

At harvest, a representative sample of corn grain from each of the four hybrids was obtained and sent to the Dairy One, Inc., Forage Testing Laboratory (Ithaca, $\mathrm{NY}$ ) where samples were assayed for ash, Kjeldahl N, ether extract (AOAC, 1990); ADF, ADICP, ADL, NDF with heat-stable $\alpha$-amylase and sodium sulfite (Van Soest et al., 1991); and Ca, P, Mg, and K by inductively coupled plasma spectrometry. The NFC content of the grain was determined by calculation. Before the onset of the animal experiment, samples of corn silage were taken from a core near the end of each silo bag, packed in plastic containers with dry ice, sent to Cumberland Valley Analytical Services, Inc. (Maugansville, MD), and analyzed for $\mathrm{pH}$, mycotoxins by HPLC (aflatoxin B1, B2, G1, and G2) and TLC (zearalenone, deoxynivalenol (DON), 15 acetyl-DON, 3 acetyl-DON, and T-2 toxin), ammonia-N, lactic acid, and VFA by GLC.

Feed offered and refused was recorded daily. During the last 2 wk of each period, samples of orts were col- lected daily, and DM content was determined by drying samples from individual cows at $105^{\circ} \mathrm{C}$ for $24 \mathrm{~h}$. Samples of forages, concentrates, and TMR were collected once weekly and divided into two representative subsamples. One subsample of feed was used to determine DM as described for orts and the other subsample was stored frozen at $-20^{\circ} \mathrm{C}$ for later analyses. At the end of each experimental period, feed subsamples from the weekly collections were thawed, combined on an equal wet weight basis, and sent to the Dairy One, Inc., Forage Testing Laboratory (Ithaca, NY) where they were analyzed for ash, Kjeldahl N, ether extract, ADF, ADIN, $\mathrm{ADL}, \mathrm{NDF}, \mathrm{NFC}, \mathrm{Ca}, \mathrm{P}, \mathrm{Mg}$, and $\mathrm{K}$ using the methods described above. The DM concentration of the TMR and orts was used to calculate DMI. Subsequently, intakes of $\mathrm{ADF}, \mathrm{NDF}, \mathrm{CP}$, and NFC were estimated using the calculated DMI and the determined chemical composition of the TMR.

Milk production was recorded automatically at each milking throughout the experiment. Milk samples were collected for four consecutive milkings during each of the last 2 wk of each period, preserved with 2-bromo2-nitropropane-1,3-diol, and stored at $4^{\circ} \mathrm{C}$. At the end of each week, samples were sent to Dairy One Cooperative, Inc., Milk Check Laboratory (Ithaca, NY) for analyses of fat, CP, true protein, lactose, total solids, MUN, and SCC by infrared procedures (Foss 4000; Foss North America, Eden Prairie, MN). Daily milk composition was estimated as an average of the a.m. and p.m. milk 
samples corrected by the proportion of daily production at that milking.

Body weights and BCS were recorded during two consecutive days just before the experiment was started and on d 27 and 28 of each experimental period. Over the course of the study, BCS were determined by the same two individuals using a 5.00 scale in quarterpoint increments, where $1=$ thin and $5=$ fat (Wildman et al., 1982).

\section{Statistical Analyses}

Before analysis, data for DMI, nutrient intakes, milk production, and milk composition were reduced to period means for each cow. Thereafter, data were analyzed using the MIXED procedure of SAS (2000) for a replicated $4 \times 4$ Latin square, with square and cow treated as random variables. The following model was used for all dependent variables:

$$
\mathrm{Y}_{\mathrm{ijkl}}=\mu+\mathrm{S}_{\mathrm{i}}+\mathrm{C}_{\mathrm{j}}(\mathrm{S})_{\mathrm{i}}+\mathrm{P}_{\mathrm{k}}+\mathrm{SP}_{\mathrm{ik}}+\mathrm{T}_{1}+\mathrm{ST}_{\mathrm{il}}+\varepsilon_{\mathrm{ijk}},
$$

where:

$$
\begin{aligned}
\mu & =\text { overall mean, } \\
\mathrm{S}_{\mathrm{i}} & =\text { effect of square } \mathrm{i}(\mathrm{i}=1,2,3,4), \\
\mathrm{C}_{\mathrm{j}}(\mathrm{S})_{\mathrm{i}}= & \text { effect of cow } \mathrm{j} \text { nested within square } \mathrm{i}(\mathrm{j}= \\
& 1,2,3,4), \\
\mathrm{P}_{\mathrm{k}} & =\text { effect of period } \mathrm{k}(\mathrm{k}=1,2,3,4), \\
\mathrm{SP}_{\mathrm{ik}} & =\text { interaction of square } \mathrm{i} \text { and period } \mathrm{k}, \\
\mathrm{T}_{1}= & \text { effect of treatment } 1(\mathrm{l}=1,2,3,4), \\
\mathrm{ST}_{\mathrm{il}}= & \text { interaction of square } \mathrm{i} \text { and treatment } 1, \\
& \text { and } \\
\varepsilon_{\mathrm{ijkl}}= & \text { residual error. }
\end{aligned}
$$

Least square means were separated into significant main effects by the PDIFF procedure of SAS (2000). Differences among treatments were considered to be significant when $P<0.05$, whereas when $P>0.05$ but $<0.10$ differences were considered to indicate a trend towards a significant effect.

\section{RESULTS AND DISCUSSION}

\section{Chemical Composition of Feed Ingredients and Diets}

Except for few small differences of questionable biological relevance, the chemical composition of corn grain from the NK603 hybrid and its nontransgenic control were similar (Table 2). In addition, the composition of these two hybrids was substantially equivalent to that of conventional hybrids of similar maturity (about 2500 heat units) available on the marketplace (i.e., DK647 and RX740). Recently, Sidhu et al. (2000) reported similar results for grain from a glyphosatetolerant hybrid (event GA21), its parental control, and five conventional corn hybrids. Furthermore, values shown in Table 2 for all hybrids are within the range reported in the literature for dry corn grain (Miller and Hoover, 1998; NRC, 2001).

Similarly, no relevant differences were observed for the chemical composition of corn silage produced either from the NK603 hybrid or its nontransgenic control line (Table 3). Apart from the content of DM, the composition of these two silages was equivalent to that of the RX740 corn silage (Table 3). As shown in Table 3, the RX740 silage contained about 5 percentage units less DM than the other three corn silages, denoting the lower DM content of the RX740 whole-cut plants at harvest ( 6 percentage units). The DK647 corn silage provided the largest concentration of $\mathrm{ADF}$ and $\mathrm{NDF}$ and the lowest content of CP and NFC (Table 3). More important, however, is the fact that the chemical composition of the four corn silages was within published literature ranges (Miller and Hoover, 1998; NRC, 2001). In comparison with the control and commercial corn silages, the $\mathrm{pH}$ and contents of $\mathrm{NH}_{3} \mathrm{~N}$, lactic acid, and acetic acid were slightly higher for the NK603 silage (Table 3). Almost certainly, however, these differences were not biologically significant. Moreover, the $\mathrm{pH}$ and concentration of organic acids in all corn silages, particularly their large content of lactic acid ( $>86 \%$ of total VFA), reveal the occurrence of desirable fermentation processes (Pitt, 1990) that resulted in well-preserved forages.

Additionally, mycotoxins were not detected in most of the corn silage samples (data not shown). However, small amounts of DON were detected in one each of three samples for NK603 $(0.7 \mathrm{mg} / \mathrm{kg})$, nontransgenic control $(0.6 \mathrm{mg} / \mathrm{kg})$, and DK647 $(1.0 \mathrm{mg} / \mathrm{kg})$, and two of three samples for RX740 (0.9 and $0.7 \mathrm{mg} / \mathrm{kg})$ corn silages. These concentrations of DON were below concentrations ( 1.5 to $2.5 \mathrm{mg} / \mathrm{kg}$ ) considered harmful to cattle. The DON was not detected in the other samples of corn silage that were assayed.

Concentrations of chemical components were equivalent among experimental diets, except for the lower $\mathrm{CP}$ percentage of the DK647 diet (Table 4). Because only the source of corn grain and silage differed among diets, this divergence can be attributed to the lower content of CP in grain (Table 3) and silage (Table 4) produced from DK647. All diets, however, met or exceeded the requirements (NRC, 2001) for CP, RUP, and RDP by cows used in this experiment.

\section{Intake of DM, CP, ADF, NDF, and NFC}

The intake of DM tended to be altered by dietary treatments (Table 5). On average, feeding the NK603 
Table 2. Chemical composition of corn grain from a glyphosate-tolerant hybrid (event NK603), its nontransgenic control line, and two nontransgenic commercial corn hybrids.

\begin{tabular}{|c|c|c|c|c|}
\hline \multirow[b]{2}{*}{ Item } & \multicolumn{4}{|c|}{ Hybrids } \\
\hline & $\begin{array}{l}\text { Glyphosate } \\
\text { tolerant }\end{array}$ & $\begin{array}{l}\text { Nontransgenic } \\
\text { control }\end{array}$ & DK647 & RX740 \\
\hline & & $-(\%$ of & & \\
\hline DM & 85.4 & 85.3 & 85.4 & 86.5 \\
\hline $\mathrm{CP}$ & 9.3 & 8.6 & 8.1 & 9.4 \\
\hline $\mathrm{ADICP}^{1}$ & 0.3 & 0.5 & 0.6 & 0.4 \\
\hline NDF & 8.3 & 8.5 & 8.6 & 8.6 \\
\hline $\mathrm{ADF}$ & 2.7 & 3.7 & 4.1 & 4.4 \\
\hline $\mathrm{ADL}^{2}$ & 1.2 & 1.4 & 1.0 & 1.1 \\
\hline NSC & 76.6 & 77.7 & 78.6 & 76.3 \\
\hline $\mathrm{EE}^{3}$ & 4.6 & 4.1 & 4.0 & 4.4 \\
\hline Ash & 1.39 & 1.56 & 1.27 & 1.42 \\
\hline $\mathrm{Ca}$ & $\mathrm{ND}^{4}$ & ND & ND & ND \\
\hline $\mathrm{P}$ & 0.34 & 0.34 & 0.34 & 0.36 \\
\hline $\mathrm{Mg}$ & 0.12 & 0.11 & 0.11 & 0.11 \\
\hline $\mathrm{K}$ & 0.35 & 0.37 & 0.36 & 0.32 \\
\hline
\end{tabular}

${ }^{1}$ Acid detergent insoluble CP.

${ }^{2}$ Acid detergent lignin.

${ }^{3}$ Ether extract.

${ }^{4}$ Not detected.

Table 3. Chemical composition, $\mathrm{pH}$, and organic acid concentrations of corn silage produced from a glyphosate-tolerant hybrid (event NK603), its nontransgenic control line, and two nontransgenic commercial hybrids and alfalfa silage.

\begin{tabular}{|c|c|c|c|c|c|}
\hline \multirow[b]{2}{*}{ Item } & \multirow[b]{2}{*}{$\begin{array}{l}\text { Alfalfa } \\
\text { silage }\end{array}$} & \multicolumn{4}{|c|}{ Corn silages } \\
\hline & & $\begin{array}{l}\text { Glyphosate } \\
\text { tolerant }\end{array}$ & $\begin{array}{l}\text { Nontransgenic } \\
\text { control }\end{array}$ & DK647 & RX740 \\
\hline & & & $(\%$ of $\mathrm{DM})$ & & \\
\hline $\mathrm{DM}$ & 56.0 & 40.6 & 40.9 & 39.7 & 35.5 \\
\hline $\mathrm{CP}$ & 21.5 & 8.3 & 7.5 & 7.0 & 8.1 \\
\hline $\mathrm{ADICP}^{1}$ & 2.0 & 1.1 & 0.8 & 0.7 & 0.7 \\
\hline NDF & 45.8 & 35.2 & 35.0 & 41.1 & 36.3 \\
\hline $\mathrm{ADF}$ & 37.1 & 20.2 & 20.4 & 24.5 & 20.9 \\
\hline $\mathrm{ADL}^{2}$ & $\mathrm{ND}^{3}$ & 3.5 & 2.7 & 3.0 & 4.1 \\
\hline NFC & 24.5 & 48.1 & 49.0 & 43.4 & 47.1 \\
\hline $\mathrm{EE}^{4}$ & ND & 2.9 & 3.1 & 2.8 & 3.2 \\
\hline Ash & ND & 4.1 & 4.1 & 3.7 & 4.5 \\
\hline $\mathrm{Ca}$ & 1.25 & 0.23 & 0.19 & 0.20 & 0.18 \\
\hline $\mathrm{P}$ & 0.25 & 0.17 & 0.17 & 0.16 & 0.17 \\
\hline $\mathrm{Mg}$ & 0.24 & 0.17 & 0.14 & 0.14 & 0.13 \\
\hline $\mathrm{K}$ & 1.98 & 0.86 & 0.96 & 0.92 & 1.10 \\
\hline $\mathrm{pH}$ & ND & 4.01 & 3.85 & 3.84 & 3.74 \\
\hline $\mathrm{NH}_{3} \mathrm{~N}^{5}$ & ND & 0.55 & 0.38 & 0.40 & 0.40 \\
\hline Lactic acid & ND & 5.73 & 5.08 & 4.60 & 6.18 \\
\hline Acetic acid & ND & 0.91 & 0.65 & 0.87 & 0.78 \\
\hline Propionic acid & ND & $<0.01$ & $<0.01$ & 0.05 & $<0.01$ \\
\hline Butyric acid & ND & $<0.01$ & $<0.01$ & $<0.01$ & $<0.01$ \\
\hline Total acids & ND & 6.64 & 5.72 & 5.52 & 6.96 \\
\hline
\end{tabular}

\footnotetext{
${ }^{1}$ Acid detergent insoluble CP.

${ }^{2}$ Acid detergent lignin.

${ }^{3}$ Not determined.

${ }^{4}$ Ether extract.

${ }^{5}$ Ammonia nitrogen.
} 
Table 4. Chemical composition of the experimental diets.

\begin{tabular}{|c|c|c|c|c|}
\hline \multirow[b]{2}{*}{ Item } & \multicolumn{4}{|c|}{ Treatments } \\
\hline & $\begin{array}{l}\text { Glyphosate } \\
\text { tolerant }^{1}\end{array}$ & $\begin{array}{l}\text { Nontransgenic } \\
\text { control }\end{array}$ & DK647 & RX740 \\
\hline & & - $(\%$ of & & \\
\hline $\mathrm{DM}$ & 58.0 & 58.5 & 58.5 & 54.4 \\
\hline $\mathrm{CP}$ & 17.7 & 17.4 & 15.9 & 18.0 \\
\hline $\mathrm{ADICP}^{2}$ & 0.9 & 0.8 & 0.8 & 0.9 \\
\hline NDF & 27.9 & 27.6 & 28.9 & 29.2 \\
\hline $\mathrm{ADF}$ & 18.9 & 17.5 & 19.1 & 19.5 \\
\hline $\mathrm{ADL}^{3}$ & 4.0 & 3.5 & 3.7 & 3.4 \\
\hline NFC & 44.1 & 44.8 & 45.8 & 41.9 \\
\hline $\mathrm{EE}^{4}$ & 3.5 & 3.4 & 3.3 & 3.9 \\
\hline Ash & 7.8 & 7.6 & 6.9 & 8.0 \\
\hline $\mathrm{Ca}$ & 0.88 & 0.95 & 0.79 & 0.86 \\
\hline $\mathrm{P}$ & 0.47 & 0.48 & 0.43 & 0.48 \\
\hline $\mathrm{Mg}$ & 0.31 & 0.29 & 0.28 & 0.31 \\
\hline $\mathrm{K}$ & 1.31 & 1.29 & 1.26 & 1.42 \\
\hline
\end{tabular}

and DK647 diets decreased DMI by $1.25 \mathrm{~kg} / \mathrm{d}$ when compared with the nontransgenic control and RX740 diets. It should be noticed, however, that the DMI of cows fed the NK603 diet was only $0.9 \mathrm{~kg} / \mathrm{d}$ lower than the DMI of cows fed the control diet (Table 5). Furthermore, cows consumed almost identical amounts of the NK603 and DK647 diets (Table 5). In agreement with these findings, Donkin (personal communication, 2000) reported that when lactating dairy cows ranging from 71 to 107 DIM were fed diets that contained $62 \%$ corn silage and $17 \%$ corn grain from either a glyphosatetolerant (GA21) or a nontransgenic control (DK626) differences in DMI (21.9 and $21.5 \mathrm{~kg} / \mathrm{d}$, respectively) were not significant. Likewise, the feeding of glyphosate-tolerant or nontransgenic (i.e., control and commercial lines) corn grain to broilers (Taylor et al., 2001b) and pigs (event GA21; Stanisiewski et al., 2001) resulted in similar feed intakes.
Cows fed the diets that contained the NK603 and nontransgenic control hybrid did not differ in intakes of $\mathrm{CP}, \mathrm{ADF}, \mathrm{NDF}$, and NFC (Table 5). However, there were some significant differences in intakes of $\mathrm{CP}, \mathrm{ADF}$, and NDF among other treatments. The intake of CP by cows fed the NK603 and nontransgenic control hybrid was intermediate compared with DK647 and RX740 hybrids. Intake of CP was lowest for cows fed the DK647 treatment because the CP content of the diet and DMI were slightly lower than for other treatments. The highest intake of $\mathrm{CP}$ was for cows fed the RX740 hybrid because the CP content and DMI of this diet were slightly higher than for the other treatments. Intakes of $\mathrm{ADF}$ and $\mathrm{NDF}$ were greater for cows fed the RX740 hybrid than for the other three treatments because of the slightly greater DMI and $\mathrm{ADF}$ and NDF contents of the diet. Cows fed all treatments consumed similar amounts of NFC. Therefore, differences that

Table 5. Least square means for intakes of DM, CP, ADF, NDF, and NFC by lactating dairy cows fed corn silage and grain from either a glyphosate-tolerant (event NK603), its nontransgenic control line, or two nontransgenic commercial hybrids.

\begin{tabular}{|c|c|c|c|c|c|c|}
\hline \multirow[b]{2}{*}{ Item } & \multicolumn{4}{|c|}{ Treatments } & \multirow[b]{2}{*}{ SEM } & \multirow[b]{2}{*}{$P$} \\
\hline & $\begin{array}{l}\text { Glyphosate } \\
\text { tolerant }\end{array}$ & $\begin{array}{l}\text { Nontransgenic } \\
\text { control }\end{array}$ & DK647 & RX740 & & \\
\hline & 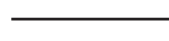 & $-(\mathrm{kg} / \mathrm{d})$ & 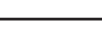 & 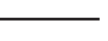 & & \\
\hline DM & 24.6 & 25.5 & 24.5 & 26.1 & 0.8 & 0.06 \\
\hline CP & $4.4^{\mathrm{a}}$ & $4.4^{\mathrm{a}}$ & $3.9^{\mathrm{b}}$ & $4.7^{\mathrm{c}}$ & 0.2 & $<0.01$ \\
\hline $\mathrm{ADF}$ & $4.7^{\mathrm{a}}$ & $4.5^{\mathrm{a}}$ & $4.7^{\mathrm{a}}$ & $5.1^{\mathrm{b}}$ & 0.3 & $<0.01$ \\
\hline NDF & $6.9^{\mathrm{a}}$ & $7.0^{\mathrm{a}}$ & $7.1^{\mathrm{a}}$ & $7.6^{\mathrm{b}}$ & 0.4 & 0.03 \\
\hline $\mathrm{NFC}$ & 10.8 & 11.4 & 11.2 & 11.0 & 0.6 & 0.16 \\
\hline
\end{tabular}

${ }^{\mathrm{a}, \mathrm{b}, \mathrm{c}}$ Values within the same row with uncommon superscript are different $(P<0.05)$. 
Table 6. Least square means for milk production, milk composition, BW change, and BCS of dairy cows fed corn silage and grain from either a glyphosate-tolerant (event NK603), its nontransgenic control line, or two nontransgenic commercial hybrids.

\begin{tabular}{|c|c|c|c|c|c|c|}
\hline \multirow[b]{2}{*}{ Item } & \multicolumn{4}{|c|}{ Treatments } & \multirow[b]{2}{*}{ SEM } & \multirow[b]{2}{*}{$P$} \\
\hline & $\begin{array}{l}\text { Glyphosate } \\
\text { tolerant }\end{array}$ & $\begin{array}{l}\text { Nontransgenic } \\
\text { control }\end{array}$ & DK647 & RX740 & & \\
\hline Milk, kg/d & 31.1 & 32.8 & 31.4 & 32.9 & 2.26 & 0.14 \\
\hline $\begin{array}{l}\text { Fat } \\
\% \\
\mathrm{~kg} / \mathrm{d}\end{array}$ & $\begin{array}{l}3.66 \\
1.15\end{array}$ & $\begin{array}{l}3.70 \\
1.21\end{array}$ & $\begin{array}{l}3.69 \\
1.16\end{array}$ & $\begin{array}{l}3.68 \\
1.21\end{array}$ & $\begin{array}{l}0.01 \\
0.07\end{array}$ & $\begin{array}{l}0.97 \\
0.16\end{array}$ \\
\hline $\begin{array}{l}3.5 \% \mathrm{FCM},{ }^{1} \mathrm{~kg} / \mathrm{d} \\
\mathrm{CP}\end{array}$ & 32.0 & 33.8 & 32.3 & 33.8 & 2.08 & 0.10 \\
\hline & $\begin{array}{l}3.26 \\
1.01\end{array}$ & $\begin{array}{l}3.29 \\
1.08\end{array}$ & $\begin{array}{l}3.28 \\
1.03\end{array}$ & $\begin{array}{l}3.25 \\
1.06\end{array}$ & $\begin{array}{l}0.07 \\
0.06\end{array}$ & $\begin{array}{l}0.32 \\
0.21\end{array}$ \\
\hline $\begin{array}{l}\text { True protein } \\
\% \\
\mathrm{~kg} / \mathrm{d}\end{array}$ & $\begin{array}{l}3.06 \\
0.95\end{array}$ & $\begin{array}{l}3.10 \\
1.01\end{array}$ & $\begin{array}{l}3.09 \\
0.97\end{array}$ & $\begin{array}{l}3.05 \\
1.0\end{array}$ & $\begin{array}{l}0.07 \\
0.05\end{array}$ & $\begin{array}{l}0.35 \\
0.23\end{array}$ \\
\hline $\mathrm{MUN},{ }^{2} \mathrm{mg} / \mathrm{dl}$ & 15.6 & 14.7 & 14.9 & 15.7 & 0.77 & 0.10 \\
\hline $\begin{array}{l}\text { Lactose } \\
\% \\
\mathrm{~kg} / \mathrm{d}\end{array}$ & $\begin{array}{l}4.69 \\
1.48\end{array}$ & $\begin{array}{l}4.77 \\
1.57\end{array}$ & $\begin{array}{l}4.78 \\
1.51\end{array}$ & $\begin{array}{l}4.77 \\
1.57\end{array}$ & $\begin{array}{l}0.09 \\
0.13\end{array}$ & $\begin{array}{l}0.33 \\
0.20\end{array}$ \\
\hline $\begin{array}{l}\text { Total solids } \\
\% \\
\mathrm{~kg} / \mathrm{d}\end{array}$ & $\begin{array}{r}12.33 \\
3.86\end{array}$ & $\begin{array}{r}12.37 \\
4.06\end{array}$ & $\begin{array}{r}12.46 \\
3.92\end{array}$ & $\begin{array}{r}12.41 \\
4.08\end{array}$ & $\begin{array}{l}0.17 \\
0.26\end{array}$ & $\begin{array}{l}0.72 \\
0.17\end{array}$ \\
\hline $\begin{array}{l}\text { SCC, } 10^{3} \text { cells } / \mathrm{ml} \\
\text { SCC, log } 10\end{array}$ & $\begin{array}{r}175.5 \\
5.07\end{array}$ & $\begin{array}{r}178.0 \\
5.09\end{array}$ & $\begin{array}{r}143.3 \\
5.06\end{array}$ & $\begin{array}{l}172.7 \\
5.11\end{array}$ & $\begin{array}{r}42.37 \\
0.11\end{array}$ & 0.90 \\
\hline $\begin{array}{l}\text { BW change } \\
\text { total } \mathrm{kg} / 28 \mathrm{~d} \\
\mathrm{~kg} / \mathrm{d}\end{array}$ & $\begin{array}{c}12.8 \\
0.46\end{array}$ & $\begin{array}{l}17.0 \\
0.61\end{array}$ & $\begin{array}{c}11.5 \\
0.41\end{array}$ & $\begin{array}{c}17.7 \\
0.63\end{array}$ & $\begin{array}{l}4.35 \\
0.16\end{array}$ & $\begin{array}{l}0.48 \\
0.48\end{array}$ \\
\hline $\mathrm{BCS}^{3}$ & 2.84 & 2.84 & 2.87 & 2.84 & 0.12 & 0.66 \\
\hline
\end{tabular}

${ }^{1} 3.5 \% \mathrm{FCM}=0.4324$ (kilograms of milk) +16.216 (kilograms of fat).

${ }^{2}$ Milk urea nitrogen.

${ }^{3}$ Body condition score on a 5.00 scale in quarter point increments where $1=$ thin and $5=$ fat (Wildman et al., 1982).

occurred in intakes of $\mathrm{CP}, \mathrm{ADF}$, and NDF arose from the small variations in both DMI and chemical composition of feed ingredients and experimental diets.

\section{Production of Milk and Milk Composition}

For all treatments, the production of milk and 3.5\% FCM averaged 32 and $33 \mathrm{~kg} / \mathrm{d}$ per cow, respectively, and were not significantly different among treatments (Table 6). Likewise, the concentration of fat, CP, true protein, MUN, lactose, and total solids in milk did not differ among treatments (Table 6). Consequently, the production of milk components was unaffected by experimental diets (Table 6). Additionally, SCC averaged 167 $\left(10^{3} / \mathrm{ml}\right)$ for all treatments and significant differences were not evident when SCC were transformed (log 10) before performing the statistical analysis (Table 6). These results agree with data of Donkin (personal communication, 2000) indicating that milk production, milk composition, and udder health of cows fed glyphosatetolerant (GA21) corn or its nontransgenic control line
(DK626) did not differ. In contrast, Grant (2003) reported that production of milk and $4 \%$ FCM was decreased when glyphosate-tolerant (event NK603) corn grain and corn silage were fed to dairy cows. This decrease in production was attributed to the glyphosatetolerant corn silage having a higher than desired DM content $(42.5 \%)$ compared with its nontransgenic control $(36.6 \%)$ because of extremely fast drying conditions at harvest. The higher DM content of the glyphosatetolerant corn silage resulted in a less desirable fermentation pattern and a $2.8 \mathrm{~kg} / \mathrm{d}$ per cow lower DMI resulting, in turn, in a decrease in milk production (3.3 $\mathrm{kg} / \mathrm{d}$ per cow) compared with controls.

All dietary treatments supplied nutrients for cows to gain BW at a similar average daily gain $(0.53 \mathrm{~kg} / \mathrm{d}$ per cow; Table 6). Additionally, BCS averaged 2.85 and remained unaltered among cows fed NK603 or nontransgenic corns (Table 6).

These findings support published data showing that the performance (Gaines et al., 2001a; Stanisiewski et al., 2001; Taylor et al., 2001a, 2001b) and meat composi- 
tion (Stanisiewski et al., 2001; Taylor et al., 2001a, 2001b) of chickens and pigs is not affected by the feeding of glyphosate-tolerant corn.

\section{CONCLUSIONS}

Data from this experiment indicate that the chemical composition of corn grain and corn silage produced from a corn line tolerant to glyphosate (NK603) is substantially equivalent to that of its nontransgenic control line and conventional corn hybrids (DK647 and RX740). Furthermore, our findings confirmed that the attainable animal response from the feeding of glyphosatetolerant corn as grain and(or) silage to lactating dairy cows is not different from the feeding of nontransgenic corn lines. Therefore, the stable insertion of the gene that confers tolerance to glyphosate (event NK603) in the corn line used in this experiment does not affect its nutritional value for lactating dairy cows.

\section{REFERENCES}

Association of Official Analytical Chemists. 1990. Official Methods of Analysis. Vol. I, 15th ed. AOAC, Arlington, VA.

Clark, J. H., and I. R. Ipharraguerre. 2001. Livestock performance: Feeding biotech crops. J. Dairy Sci. 84(E. Suppl.):E9-E18.

Gaines, A. M., G. L. Allee, and B. W. Ratliff. 2001a. Nutritional evaluation of Bt (MON810) and Roundup Ready ${ }^{\circledR}$ corn compared with commercial hybrids in broilers. Poult. Sci. 80(Suppl. 1):51. (Abstr.)

Gaines, A. M., G. L. Allee, and B. W. Ratliff. 2001b. Swine digestible energy evaluations of Bt (MON810) and Roundup Ready ${ }^{\circledR}$ corn compared with commercial varieties. Poult. Sci. 80(Suppl. 1):109. (Abstr.)

Grant, R. J. 2003. Influence of glyphosate-tolerant (event NK603) and corn root worm protected (event MON863) corn silage and grain on feed intake and milk production in Holstein cattle. J. Dairy Sci. 85:1715-1723.

Miller, T. K., and W. H. Hoover. 1998. Nutrient Analyses of Feedstuff Including Carbohydrates. Animal Science Report No. 1. West Virginia Univ., Morgantown.

National Research Council. 2001. Nutrient Requirements of Dairy Cattle. 7th rev. ed. Natl. Acad. Sci., Washington, DC.

Pitt, R. E. 1990. Silage and hay preservation. NRAES-5. Northeast Regional Agricultural Engineering Service, Ithaca, NY.

SAS. 2000. The SAS System for Windows. Release 8.1 (TS1 MO). SAS Institute, Inc., Cary, NC.

Sidhu, R. S., B. G. Hammond, R. L. Fuchs, J. Mutz, L. R. Holden, B. George, and T. Olson. 2000. Glyphosate-tolerant corn: The composition and feeding value of grain from glyphosate-tolerant corn is equivalent to that of conventional corn (Zea mays L.). J. Agric. Food Chem. 48:2305-2312.

Stanisiewski, E. P., G. F. Hartnell, and D. R. Cook. 2001. Comparison of swine performance when fed diets containing Roundup Ready ${ }^{\circledR}$ corn (GA21), parental line, or conventional corn. J. Anim. Sci. 84(Suppl. 1):319. (Abstr.)

Steinrüken, H. C., and N. Amrhein. 1980. The herbicide glyphosate is a potent inhibitor of 5-enolpyruvyl-shikimate-3-phosphate synthase. Biochem. Biophys. Res. Comm. 94:1207-1212.

Taylor, M. L., G. F. Hartnell, M. A. Nemeth, B. George, and J. D. Astwood. 2001a. Comparison of broiler performance when fed diets containing Roundup Ready ${ }^{\circledR}$ corn event NK603, parental line, or commercial corn. J. Anim. Sci. 84(Suppl. 1):320. (Abstr.)

Taylor, M. L., G. F. Hartnell, M. A. Nemeth, B. George, and J. D. Astwood. 2001b. Comparison of broiler performance when fed diets containing YieldGard ${ }^{\circledR}$ corn, YieldGard ${ }^{\circledR}$ and Roundup Ready ${ }^{\circledR}$ corn, parental lines, or commercial corn. J. Animal Sci. 84(Suppl. 1):319. (Abstr.)

USDA. 2001. Subject: Agricultural Biotechnology. http://www.usda.gov/agencies/biotech/research html. Accessed Dec. 7, 2001.

Van Soest, P. J., J. B. Robertson, and B. A. Lewis. 1991. Methods for dietary fiber, neutral detergent fiber, and nonstarch polysaccharides in relation to animal nutrition. J. Dairy Sci. 74:35833597.

Wildman, E. E., G. M. Jones, P. E. Wagner, R. L. Boman, H. F. Troutt, Jr., and T. N. Lesch. 1982. A dairy cow body condition scoring system and its relationship to selected production characteristics. J. Dairy Sci. 65:495-501. 